\title{
Ammoniation of barley straw : effect on anatomical and physicochemical characteristics of the cell walls
}

\author{
M Goto \\ Faculty of Bioresources, Mie University, Tsu 514, Japan
}

The objective of this study was to investigate changes in chemical and structural features of the cell walls in barley straw (Hordium vulgare L.) following treatment with ammonia ( $30 \mathrm{~g} \mathrm{NH}_{3} / \mathrm{kg}$ straw) and to relate to the improvement in cell-wall degradability by rumen microorganisms.

Stem specimens of untreated and ammoniatreated straw were prepared for SEM and TEM observations. Water and methanol-extracts of finely ground stem samples were subjected to IR spectrometry and appropriate chemical analysis. The $\mathrm{X}$-ray diffraction patterns, waterholding capacity and swollen volume were also examined.

Changes in chemical composition of barley straw following the treatment were seen as an increase in the nitrogen content of the cell-wall fraction and as a partial loss of ester-linked phenolic acids and acetyl groups. Ammonia treatment promoted access by rumen microorganisms to the luminal surface of parenchyma and sclerenchyma cells apparently due to an alteration in the fragility of a thinner, rigid layer covering the inner surface of cell walls. Two measures of the X-ray diffraction pattern in treated straw indicated that treatment of barley straws produced a significant reduction in crystallinity index values of $14-24 \%$. The water retention of the treated barley straw was $30 \%$ greater than that of the untreated straw following centrifugation at $300 \times g$ and $3000 \times g$. A slightly higher swollen volume was also observed for water-saturated ammonia-treated barley straw, although the difference was not significant.

It is suggested that two major consequences of treatment : the effect of ammonia as weak base on ester bonding within the cell wall and the ability of ammonia in an undissociated form to affect cellulose crystallinity, combine to increase the degradability of the treated straw.

\begin{tabular}{lcccc}
\hline & $\begin{array}{c}\text { Ratio of height : } \\
\text { width of the main } \\
\text { X-ray peak }\end{array}$ & $300 \times g$ & $3000 \times g$ & $\begin{array}{c}\text { Swollen volume } \\
\left(\mathrm{cm}^{3 / g} \mathrm{gM}\right)\end{array}$ \\
\hline Untreated & $7.0^{\mathrm{b}}$ & $1.73^{\mathrm{a}}$ & $0.79^{\mathrm{a}}$ & $5.55^{\mathrm{a}}$ \\
Ammonia-treated & $5.3^{\mathrm{a}}$ & $2.36^{\mathrm{b}}$ & $1.02^{\mathrm{b}}$ & $5.87^{\mathrm{a}}$ \\
\hline
\end{tabular}

Means with different superscripts in the same column were significantly different $(P<0.05)$ by a Student's t-test. 